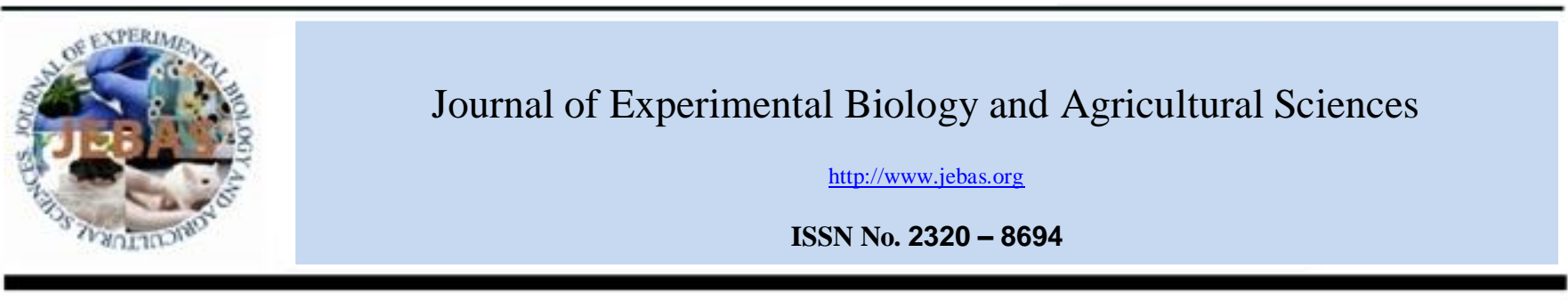

\title{
SELECTED PHYSIOLOGICAL RESPONSES OF ROSELLE (Hibiscus sabdariffa) TO DROUGHT STRESS
}

\section{Dawn Evans and Safaa Al-Hamdani*}

Department of Biology, Jacksonville State University, 700 Pelham Rd, Jacksonville, AL 36365

Received - October 05, 2015; Revision - October 29, 2015; Accepted - November 18, 2015 Available Online - December 15, 2015

DOI: http://dx.doi.org/10.18006/2015.3(6).500.507

KEYWORDS
Roselle
Drought Stress
Plant growth
Physiology
Photosynthetic rate

\begin{abstract}
This greenhouse study was carried out to determine the impact of drought on plant growth, photosynthetic rate and the recovery of photosynthesis after drought relief. Twenty four Roselle plants were equally divided between the control and the treatment groups, which received $100 \%$ and $25 \%$ soil saturation respectively. The plants were grown under greenhouse conditions with the temperature averaging $27 \pm 2^{\circ} \mathrm{C}$. The treatments were applied with seven cycles of watering until the plants reached the anthesis stage. The drought influence caused a significant reduction in the plant height, flower number, and photosynthetic rate. Re-watering the plants growing under drought to $100 \%$ water saturation resulted in complete recovery of photosynthetic rate within forty-eight hours. However, rewatering to $25 \%$ showed only $30 \%$ recovery in photosynthetic rate after forty-eight hours. Photosynthetic pigments including chlorophyll a, b and carotenoid were not significantly influenced by the drought. Similarly, total phenolic compound concentration of the calyx was insignificant between the treatments. However, Anthocyanin concentration of the calyx was significantly higher under the drought treatment.
\end{abstract}

* Corresponding author

E-mail: sah@jsu.edu (Safaa Al-Hamdani)

Peer review under responsibility of Journal of Experimental Biology and Agricultural Sciences.

Production and Hosting by Horizon Publisher (http://publisher.jebas.org/index.html).

All rights reserved.
All the article published by Journal of Experimental Biology and Agricultural Sciences is licensed under a Creative Commons Attribution-NonCommercial 4.0 International License Based on a work at www.jebas.org.

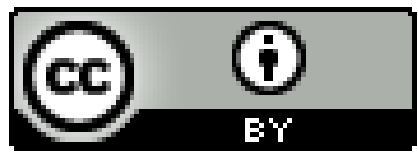




\section{Introduction}

Roselle (Hibiscus sabdariffa) belongs to the family Malvaceae. It is an erect, mostly branched, annual, herbaceous sub shrub that grows mainly in warm humid tropical and subtropical climates. Vernacular names in English speaking regions are rozelle, sorrel, and red sorrel while in Arabic it is known as karkade; in French, osielle rouge or oseille de Guinée. In Senegal Bisap is commonly used (Morton, 1987).

The stems of roselle are reddish in color, the leaves are dark green to red, and flowers are red to yellow with dark centers (Morton, 1987). Various parts of the plant including seeds, leaves, calyx and roots are used in food production. The calyces, which contain flavonoids, riboflavin, ascorbic acid, calcium, and iron, are used as a natural food dye (Morton, 1987). Additionally, the seeds of roselle are rich in protein and have been ground into a meal for human consumption in Africa. In many countries, especially in Africa, extract from the calyces is used for making hot tea or cold drink (McKay, 2009). Furthermore, Roselle calyces have been used in folk medicines for many years and have been proven effective in to lower blood pressure patients with hypertension and type II diabetes (Haji Faraji \& Haji Tarkhani, 1999). The medicinal aspects of roselle were further proven to exhibit a wide range of applications including, as a mild laxative and diuretic, for digestive and kidney functions, and treating sores and wounds (Morton, 1987).

Utilization of calyces extract was further proven to exhibit antibacterial properties toward a number of bacteria including Escherichia Coli 0157:H7 (Fullerton et al., 2011), Staphylococcus aureus (Olaleye, 2007; Yin \& Chao, 2008), Bacillus stearothermophilus, Micrococcus luteus, Serratia mascences, Bacillus cereus, Psuedomonas flourescence (Olaleye, 2007). Roselle calyces were additionally shown to interfere with aflatoxin biosynthesis in Aspergillus flavus and Aspergillus parasiticus strains (El-Nagerabi et. al. 2012). The antimicrobial properties of roselle were attributed to the presence of an abundance of secondary metabolites including a wide range of phenolic compounds (Ali et al., 2005). Additionally, some of these naturally occurring phenolic compounds have shown anti-carcinogenic, anti-hypertensive, anti-microbial, anti-mutagenic, anti-oxidative, and antiinflammatory properties (Kim \& Lee 2003; Mckay et al., 2009). Phenolic compounds are also known to have antioxidant activity and anti-mutagenic properties by binding to free radicals through their chemical structure (Bors \& Saran, 1987; Visioli et al., 1998). Anthocyanins are a subgroup of flavonoids that attract insect pollinators (Harborne \& Williams, 2000).

Plants undergo drought stress when the water supply to their roots becomes restricted or when they experience a very high transpiration rate. Plant growth and development is adversely impacted by drought stress due in part to its negative interference with the photosynthetic mechanisms including the light and dark reactions (Saibo et al., 2009). Light harvesting capacity of water stressed plants declines due to the reduction in chlorophyll $a$ and $b$ concentrations (Jaleel et al., 2009) and oxidative stress resulting from the increase in formation of reactive oxygen species (ROS) (Saibo et al., 2009). Kenaf (Hibiscus cannabinus), is closely related to the plant in this study (roselle), responded to water stress with reduced stomatal conductance, leaf rolling and reduction in water potential (Ogbonnaya et al., 1998).

In the same study, a critical water potential value below -0.5 $\mathrm{MPa}$ induced a gradual decline in Kenaf stomatal conductance and transpiration rate. Plant recovery from water stress may vary depending on the plant species (Heckathorn et al., 1997). Several studies have examined some aspect of plant physiological response recovery to drought with varying results (Subramanian \& Maheswari, 1990; Heckathorn et al., 1997; Widodo et al., 2003). Miyashita et al. (2005) found that photosynthesis was most rapid phenomena in the recovery process after water stress relief in kidney beans (Phaseolus vulgaris) and this was followed by stomatal conductance. However, the recovery level of photosynthesis, transpiration and stomatal conductance were below half compared to the control when the drought was extended from three to seven days.

Drought stress was reported to induce oxidative stress resulting from free radical formation (Smirnoff, 1993; Johnson et al., 2003). Polyphenolic compounds are considered a major antioxidant in combating free radical induced oxidative damage in the plant due to their high reactivity as hydrogen or electron donors (Manna et al., 2002; Bolkhina et al., 2003). Several studies reported an increase in total phenolic compounds in many plant species in response to water stress (Nacif de Abreu \& Mazzafera, 2005; Parida et al., 2007; Sanchez-Rodriguez et al., 2010; Ponder \& Al-Hamdani, 2011).

In this study, the total phenolic concentration was examined in response to induced water stress during the post anthesis stage of roselle. Additionally, selected physiological responses including, photosynthetic rate, stomata conductance, osmotic potential, and photosynthetic pigments were also determined. The recovery rate of these physiological responses after drought relief was established. The selected timing of drought stress was based on the hypothesis that supports an elevation in total phenolic compound in response to drought.

\section{Methods and Materials}

\subsection{Plant growth and sample collection}

Roselle seeds were germinated under greenhouse conditions in six-inch pots containing organic soil. After two weeks, twentyfour seedlings were transplanted in to individual three-gallon pots containing commercial potting soil. The soil $\mathrm{pH}$ was 5.6 and concentrations of nitrogen, phosphorus, and potassium were 179,21 , and $200 \mathrm{ppm}$, respectively. The plants were 
allowed to grow under greenhouse conditions with continuous watering as needed until reaching the anthesis stage. At this stage, the plants were randomly divided between the control and the drought treatment. Plants growing under water stress received $25 \%$ soil water saturation in comparison to the control. The volume of water that was added to the control was determined experimentally by adding a known value of water to four pots. The average water volume retained by the soil of the individual pots was calculated. The plants under treatment were exposed to seven drought cycles. The conclusion of each cycle was determined by the visual appearance of leaf wilting. Prior to watering the plant at the end of the seventh drought cycle, photosynthetic rate was determined from six random samples of each treatment. Leaf samples for photosynthetic pigment analysis were taken from each of the plants used in gas exchange measurements. The calyxes of six randomly selected plants were harvested at the conclusion of the seventh drought cycle. The calyxes were freeze dried and later utilized in determining the total phenolic compound concentration.

After the conclusion of the gas exchange measurements, the plants under water stress treatment were divided into two groups of six plants each. One group was re-watered to receive $25 \%$ and the other $100 \%$ soil water saturation. Twenty-four and forty-eight hours later, gas exchange measurements were taken to determine the recovery rate of photosynthesis, and stomatal conductance from each of the treatments.

\subsection{Preparation of Calyx Extracts}

The calyxes were collected from each of the six selected plant samples and placed in a labeled envelope and freeze dried. Once all the moisture was removed, the individual samples were ground into a fine powder using a Wiley mill and passed through a $1 \mathrm{~mm}$ screen. A $3.0 \mathrm{~g}$ subsample of ground tissue from each sample was added to a flask containing $100 \mathrm{ml}$ of $96 \%$ methanol. The individual flasks were placed on a low speed shaker at $25^{\circ} \mathrm{C}$. The shaking process continued for 7 days to allow complete bleaching of chemicals from the tissue. After evaporating the methanol, the individual samples were stored in the refrigerator $\left(-4^{\circ} \mathrm{C}\right)$ for later use.

\subsubsection{Phenolic content}

The total phenolic content of each extract sample was determined by using Folin-Ciocalteau reagent and gallic acid as standard (concentration series from 0.03-0.2 mM). Subsamples from each extract $(50 \mathrm{mg})$ were dissolved in $25 \mathrm{ml}$ of extraction solvent ( $40 \mathrm{ml}$ acetone: $40 \mathrm{ml}$ methanol: $20 \mathrm{ml}$ water: $0.1 \mathrm{ml}$ acetic acid) and vortexed until the extract was dissolved. The samples were then placed on water bath at $60^{\circ}$ $\mathrm{C}$ for 1 hour. After cooling down to room temperature, the samples were centrifuged at $1640 \mathrm{~g}$ for 20 minutes. The supernatant was placed in a test tube and $1.0 \mathrm{ml}$ of FolinCiocalteau was added, and allowed to stand at room temperature for 5 minutes; $1.0 \mathrm{ml}$ of sodium bicarbonate solution $(0.566 \mathrm{M})$ was added and the tubes were vortexed and stored in the dark at room temperature for two hours. The total phenolic determination was measured spectrophotometrically at absorption of $726 \mathrm{~nm}$.

\subsection{Photosynthetic Measurement}

Photosynthetic rate was measured from each of the six samples of the control and drought stressed plants. The measurements were carried out after $4 \mathrm{~h}$ from the onset of the light period of the last day of the third drought cycle. The second fully expanded leaf from the apical meristem was selected for the measurements. The leaf was enclosed in the plexiglass assimilation chamber $(4.5 \times 11.8 \times 7.3 \mathrm{~cm})$ of the Li-Cor 6200 photosynthesis system (Lincoln, NE, USA) following the procedure described by McDermitt et al. (1989). Temperature, light intensity, and relative humidity were maintained near constant during all the measurements. To determine the rate of photosynthesis recovery from drought stress gas measurements were taken six hours following the re-watering process and additional measurements were taken every twenty-four hours for the following two days.

\subsection{Plant Pigments Determination}

Chlorophyll $a$ and chlorophyll $b$ were determined spectrophotomically by the method of Inskeep \& Bloom (1985). A standard hole punch was used to obtain fresh leaf tissue samples from the same leaf, which was utilized in gas exchange measurements. A total of four samples from each treatment with a total area of $0.785 \mathrm{~cm}^{2}$ and an average fresh weight of $7.27 \mathrm{mg}$ were selected for this study. The individual samples were placed in a vial containing $5 \mathrm{ml} \mathrm{N}, \mathrm{N}-$ Dimethylformamide (DMF) and incubated in the dark for 36 hours at $4^{\circ} \mathrm{C}$. The absorbance of the leaf extract from each sample was determined spectrophotometrically at $664.5 \mathrm{~nm}$ and $647 \mathrm{~nm}$. To quantify the pigment the following equation was utilized:

Chl $a=12.70 A_{664.5}-2.79 A_{647} ;$

$\mathrm{Chl} b=20.70 A_{647}-4.62 A_{664.5}$

Additional absorbance was taken at $470 \mathrm{~nm}$ in order to determine carotenoid concentration using the formula of Doong et al. (1993).

Anthocyanin concentration was determined from the calyx of the flower. Six samples were taken randomly from several flowers from each treatment. A $0.1 \mathrm{~g}$ fresh tissue sample was freeze dried in liquid nitrogen and then crushed using mortar and pestle containing $5 \mathrm{ml}$ methanol with $1 \% \mathrm{HCl}(\mathrm{v} / \mathrm{v})$. After filtering the homogenate, the absorbance of the extract was determined spectrophotometrically by the method of Mancinelli (1990). 
3 Results and Discussion

The water potential of the roselle plants was significantly reduced $(-0.87 \mathrm{MPa})$ under the induced drought conditions plants as compared to the control plants $(-1.06 \mathrm{MPa})$. The growth of the plants, represented by the plants height and flower number was significantly impacted by the reduction in water potential of the plant (Figure 1). Similarly, Ogbonnaya et al. (1998) reported that Kenaf height and flower number were significantly reduced by lowering the water potential of the leaf from -0.5 to $-1.21 \mathrm{MPa}$. Other species within the same genus such as, Hibiscus rosa-sinensis, showed a significant decrease equal to $32 \%$ and $39.6 \%$ in plant height and flower number respectively as influenced by drought stress (Hansen \& Petersen, 2004). The observed reduction in plant growth under water stress is considered a common response, which has been reported in many studies (Westgate \& Boyer, 1985; Burnett et al., 2006; Jaleel et al., 2009; Ponder \& Al-Hamdani, 2011). The influence of water stress on plant growth has been attributed to a reduction in both cell enlargement and cell division (Schuppler et al., 1998; Jaleel et al., 2009). Water availability is one of the most important environmental elements governing plant growth and development (Manivannan et al., 2007). Among the many studies covering the influence of drought on plant growth, Kalefetoğlu Macar \& Ekmekçi (2009) confirmed that drought causes a reduction in vegetative growth of chickpea (Cicer arietinum). Plant growth and development are commonly influenced by drought. In addition, drought level directly influences the severity of the impact on growth (Baeck et al., 2001).

After eight weeks of growth under the treatments with seven cycles of watering, roselle photosynthetic rate had significantly declined in the drought treatment in comparison with the control (Figure. 2). Photosynthetic rate recovery was gradual and different between the treatments (Figure.2). Plant sunder drought stress that received $100 \%$ soil water saturation recovered $46 \%$ of the photosynthetic rate after twenty-four

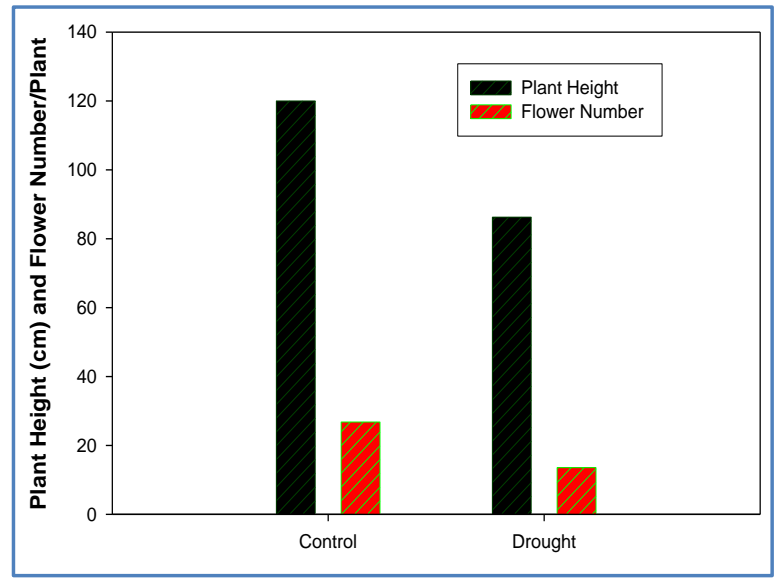

Figure 1 Influence of drought on roselle height and flower number. hours and complete recovery was obtained after forty-eight hours. However, $30 \%$ recovery was obtained in plants rewatered to $25 \%$ soil water saturation after forty-eight hours. Drought directly and indirectly impacts photosynthesis, which is one of the primary metabolic processes influencing plant growth and development (Pieters \& El Souki, 2005; Praxedes et al., 2006). Miyashita et al. (2005) reported similar recovery process to the present study in kidney beans (Phaseolus vulgaris) after forty-eight hours of re-watering in plants grown under drought stress.

The negative impact of the drought on photosynthetic rate has been well documented in the literature (Miyashita et al., 2005). However, photosynthetic response to the repeated cycle of drought and re-watering is varied among plant species and between different varieties within the same species (Izanloo et al., 2008; Xu et al., 2010). The variation response in photosynthesis is due to different adaptive mechanisms involving conferring drought tolerance (Farooq et al., 2009). These adaptations depend on the severity of the drought and the ability of the plant to respond by adjusting to the impact of stomatal or non-stomatal factors which control photosynthetic rate (Kaiser, 1987).

Rubisco activity is one of the major influences controlling photosynthetic rate, which was shown to be negatively impacted by the increase in drought level (Vu et al., 1999; Bota et al., 2004). Light reaction was reported to be impacted by drought in many different species (Epron, 1997). The decline in photosystem II during the drought period was reported to be temporarily impacted by reducing the substrate level and its function and regulation was not qualitatively obstructed (Cornic \& Fresneau, 2002). Additionally, photosynthetic rate is highly influenced by $\mathrm{CO}_{2}$ supply through the stomata to the dark reaction which can be predicted as the major factor in reducing photosynthetic rate in this study (Farquhar \& Sharkey, 1982).

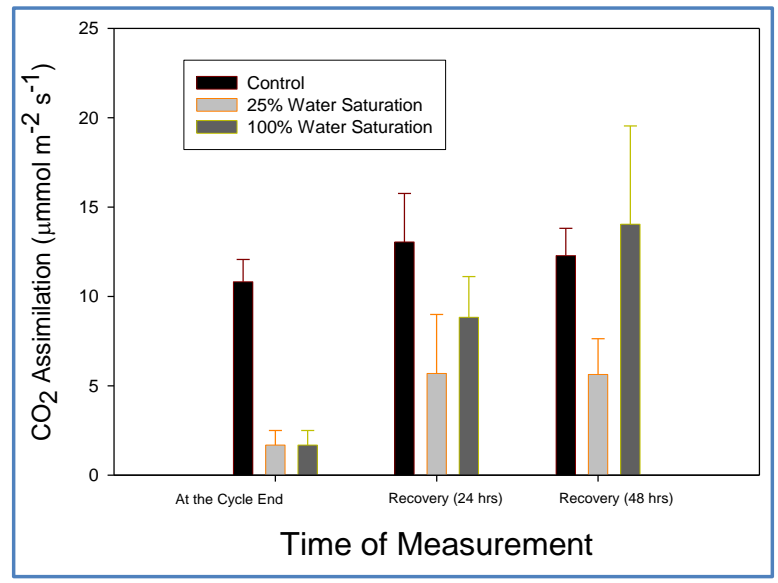

Figure 2 Influence of drought on photosynthetic rate of Roselle and the recovery of photosynthesis after re-watering. 
Table 1 Effect of Drought on Roselle Photosynthetic Pigments and Anthocyanin.

\begin{tabular}{|l|c|c|c|c|}
\hline \multicolumn{1}{|c|}{ Varieties } & $\mathrm{Chl} \mathrm{a}\left(\mathrm{mmol} \mathrm{m}{ }^{-2}\right)$ & $\mathrm{Chl} \mathrm{b}\left(\mathrm{mmol} \mathrm{m} \mathrm{m}^{-2}\right.$ & Carotenoid $\left(\mu_{\mathrm{gg} \mathrm{g}}{ }^{-1} \mathrm{FW}\right)$ & Anthocyanin $(\mu \mathrm{g} / \mathrm{FW})$ \\
\hline Control & $6.50^{\mathrm{a}}$ & $4.42^{\mathrm{a}}$ & $17.5^{\mathrm{a}}$ & $88.4^{\mathrm{a}}$ \\
\hline Drought & $7.15^{\mathrm{a}}$ & $4.85^{\mathrm{a}}$ & $19.98^{\mathrm{a}}$ & $92.2^{\mathrm{b}}$ \\
\hline
\end{tabular}

Means followed by the same letter in the each column are not significantly different based on ANOVA analysis $\mathrm{P}=0.05$.

One of the well-known plant responses to drought stress is increasing abscissic acid concentration which influences reduction in stomatal conductance to preserve water content (Xu et al., 2010). The reduction in stomatal conductance inevitably reduced internal $\mathrm{CO}_{2}$ availability to the dark reaction. This common response to drought is associated with an imbalance between the light and dark reaction, which inevitably results in over excitation of the electrons in the photosystems and formation of (ROS) (Tripathy \& Oelmuller, 2012). Both stressed and unstressed cells produce ROS, but plants undergo an increase in ROS formation under stress conditions (Alscher \& Hess, 1993). The accumulation of ROS leads to oxidative stress in plants (Jaleel et al., 2007). As a defense mechanism against the free radicals, plants generally increase the synthesis of antioxidants, specifically phenolic compounds, in response to drought stress (Nacif de Abreu \& Mazzafera, 2005; Parida et al., 2007; Sanchez-Rodriguez et al., 2010; Ponder \& Al-Hamdani, 2011).

In the present study, total phenolic compounds and flavonoids were determined from the flower calyx, and appear similarly to the control (Figure.3). However, anthocyanin, which is a subgroup of the phenolic compounds, was significantly higher in the calyx of the plant subjected to drought stress (Table 1). Additionally, photosynthetic pigments play essential roles in capturing light energy during the light reactions of photosynthesis (Smith \& French, 1963). Roselle chlorophyll $a$, $b$ and carotenoid concentrations showed no significant difference at the various watering treatments (Table 1). This indicates that a reduction of photosynthetic rate was mostly independent to the influence of photosynthetic pigment concentration. The concentration of these pigments can influence the photosynthetic rate through energy supply to the dark reactions (Farquhar \& Sharkey, 1982). In one way, oxidative stress initiates damage in the chloroplasts and cause a cascade of damaging effects including chlorophyll destruction, lipid peroxidation and protein loss. In addition, total chlorophyll generally decreases while the Chla/b ratio usually increases (Ashraf et al., 2001; Terzi \& Kadioglue, 2006; Kiani et al., 2008; Farooq et al., 2009). These observations are contradictory to the present study and no influence was of the drought reported on the photosynthetic pigments.

In conclusion, drought significantly influenced roselle growth and photosynthetic rate. However, the impact on photosynthesis was temporary and recovered with drought relief. It appeared that the reduction in water potential from 0.87 to $-1.06 \mathrm{MPa}$ was not severe enough to cause irreversible damage to the photosynthetic apparatus. This was further supported by the insignificant impact of drought on the photosynthetic pigment.

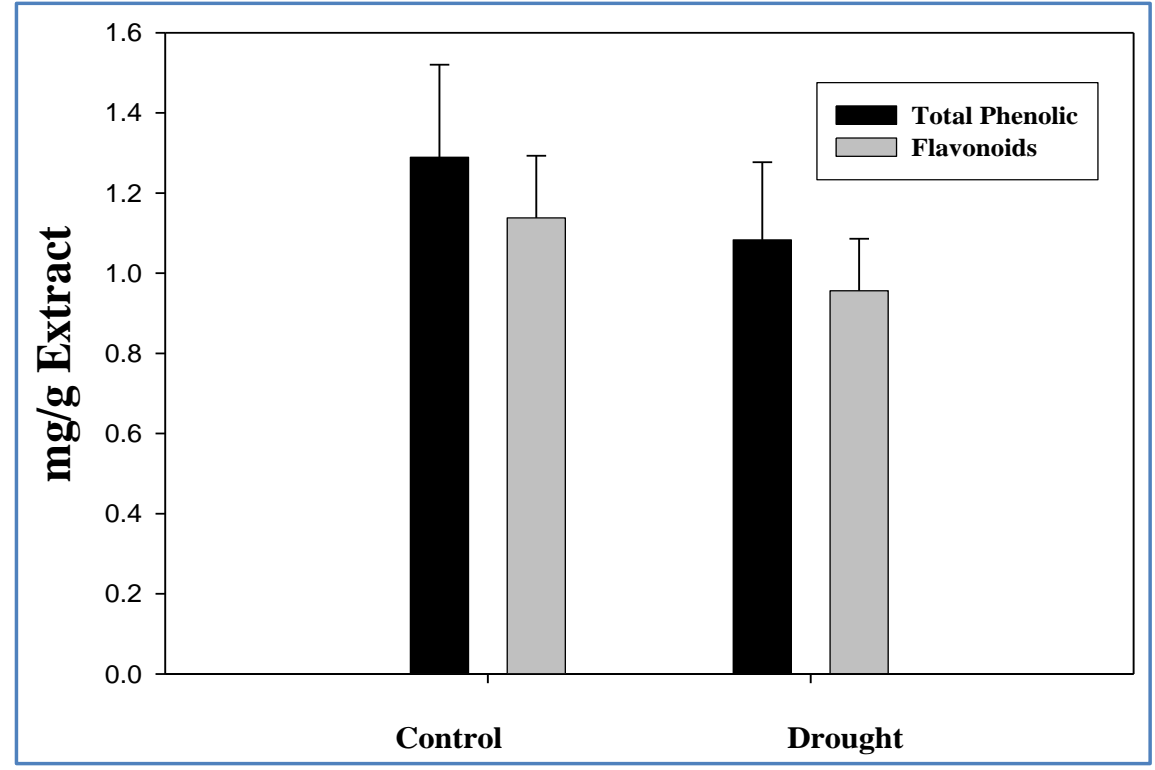

Figure 3 Influence of drought on the total phenolic compound and flavonoid concentration in Roselle calyces. 


\section{Conflict of interest}

Authors would hereby like to declare that there is no conflict of interests that could possibly arise.

\section{References}

Ali BH, Wabel NA, Blunden G (2005), Phytochemical, pharmacological and toxicological aspects of Hibiscus sabdariffa L.: a review. Phytotherapy Research 19: 369-375. doi: 10.1002/ptr.1628.

Alscher RG, Hess JL (1993) Antioxidants in higher plants. Boca Rotan, CRC press.

Ashraf M, Ahmad A, McNeilly T (2001) Growth and Photosynthetic Characteristics in Pearl Millet under Water Stress and Different Potassium Supply. Photosynthetica 39: 389-394. doi: 10.1023/A:1015182310754.

Baeck H, Kuenwoo H, Baeck HW, Park KW (2001) Effect of watering on growth and oil content of sweet basil (Ocimum americanum L.). Korean Journal of Horticultural Science and Technology 19:81-86.

Blokhina O, Virolainen E, Fagerstedt KV (2003) Antioxidants, Oxidative Damage and Oxygen Deprivation Stress: a Review. Annals of Botany 91:179-194. doi: 10.1093/aob/mcf118.

Bors W, Saran M (1987) Radical scavenging by flavonoid antioxidants. Free Radical Research Communications 2: 289294.

Bota J, Medrano H, Flexas J (2004) Is photosynthesis limited by decreased Rubisco activity and RuBP content under progressive water stress? New Phytologist 162: 671-681. doi: 10.1111/j.1469-8137.2004.01056.x.

Burnett SE, Van-Iersel MW, Thomas PA (2006) Mediumincorporated PEG-8000 Reduces Elongation, Growth, and Whole-canopy Carbon Dioxide Exchange of Marigold HortScience 41: 124-130.

Cornic G, Fresneau C (2002) Photosynthetic carbon reduction and carbon oxidation cycles are the main electron sinks for photosystem II activity during a mild drought. Annals of Botany 89: 887-894. doi: 10.1093/aob/mcf064.

Doong RL, MacDonald GE, Shilling DG (1993) Effect of fluoridone on chlorophyll, carotenoid, and anthocyanin content of Hydrilla. Journal of Aquatic Plant Management 31: 55-59.

El-Nagerabi SAF, Al-Bahry SN, Elshafie AE, Al-Hilali S (2012) Effect of Hibiscus sabdariffa extract and Nigella sativa oil on the growth and aflatoxin B1 production of Aspergillus flavus and Aspergillus parasiticus strains. Food Control 25: 59-63. doi:10.1016/j.foodcont.2011.09.033.
Epron D (1997) Effects of drought on photosynthesis and on the thermotolerance of photosystem II in seedlings of cedar (Cedrus atlantica and C. libani). Journal of Experimental Botany 48: 1835-1841. doi: 10.1093/jxb/48.10.1835.

Farooq M, Wahid A, Kobayashi N, Fujita D, Basra SMA (2009) Plant drought stress: effects, mechanisms and management. Agronomy for Sustainable Development 29:185212. doi: 10.1051/agro:2008021.

Farquhar GD, Sharkey TD (1982) Stomatal conductance and photosynthesis. Annual Review of Plant Physiology 33: 317 345. DOI: 10.1146/annurev.pp.33.060182.001533.

Fullerton M, Khatiwada J, Johnson JU, Davis S, Williams LL. (2011) Determination of antimicrobial activity of sorrel (Hibiscus sabdariffa) on Escherichia coli $\mathrm{O} 157: \mathrm{H} 7$ isolated from food, veterinary, and clinical samples. Journal of Medicinal Food 14 : 950-956. doi: 10.1089/jmf.2010.0200.

Haji Faraji M, Haji Tarkhani A (1999) The effect of sour tea (Hibiscus sabdariffa) on essential hypertension. Journal of Ethnopharmacol 65: 231-236. doi:10.1016/S03788741(98)00157-3.

Hansen CW, Petersen KK (2004) Reduced nutrient and water availability to Hibiscus rosa-sinensis 'Cairo Red' as a method to regulate growth and improve post-production quality. European Journal of Horticultural Science 69: 159-166.

Harborne JB, Williams CA (2000) Advances in flavonoid research since 1992. Phytochemistry, 55: 481-504. doi:10.1016/S0031-9422(00)00235-1.

Heckathorn SA, DeLucia EH, Zielinski RE (1997) The contribution of drought-related decreases in foliar nitrogen concentration to decreases in photosynthetic capacity during and after drought in prairie grasses. Physiologia Plantarum 101: 173-182. doi: 10.1111/j.1399-3054.1997.tb01834.x.

Inskeep WP, Bloom PR (1985) Extinction Coefficients of Chlorophyll $\mathrm{a}$ and $\mathrm{b}$ in $\mathrm{n}, \mathrm{n}$ Dimethylformamide and $80 \%$ Acetone. Plant Physiology 77: 483-485. doi: http://dx.doi.org/ 10.1104/pp.77.2.483.

Izanloo A, Condon AG, Langridge $\mathrm{P}$, Tester $\mathrm{M}$, Schnurbusch $\mathrm{T}$ (2008) Different mechanisms of adaptation to cyclic water stress in two South Australian bread wheat cultivars. Journal of Experimental Botony 59: 3327-3346. doi: 10.1093/jxb/ern 199.

Jaleel CA, Manivannan P, Sankar B, Kishorekumar A, Gopi R, Somasundaram R, Panneerselvam R (2007) Induction of drought stress tolerance by ketoconazole in Catharanthus roseus is mediated by enhanced antioxidant potentials and secondary metabolite accumulation. Colloids and Surfaces B: Biointerfaces 60: 201-206. doi:10.1016/j.colsurfb.2007.06.010. 
Jaleel CA, Manivannan P, Wahid A, Farooq M, Al-Juburi HJ, Somasundaram R, Panneerselvam R (2009) Drought Stress in Plants: A Review on Morphological Characteristics and Pigments Composition. International Journal of Agriculture \& Biology 11: 100-105.

Johnson SM, Doherty SJ, Croy RRD (2003) Biphasic superoxide generation in potato tubers. A self-amplifying response to stress. Plant Physiology 131:1440-1449. doi: http:/ /dx.doi.org/10.1104/pp.013300.

Kaiser WM (1987) Effects of water deficit on photosynthetic capacity. Physiologia Plantarum 71: 142-149. doi: 10.1111/j.1399-3054.1987.tb04631.x.

Kalefetoğlu Macar T, Ekmekçi Y (2009) Alterations in Photochemical and Physiological Activities of Chickpea (Cicer arietinum L.) Cultivars under Drought Stress. Journal of Agronomy and Crop Science 195: 335-346. doi: 10.1111/j.1439-037X.2009.00374.x

Kiani SP, Maury P, Sarrafi A, Grieu P (2008) QTL analysis of chlorophyll fluorescence parameters in sunflower (Helianthus annuus L.) under well-watered and water-stressed conditions. Plant Science 175: 565-573. doi:10.1016/j.plantsci.2008.06.002.

Kim DO, Lee CY (2003) Extraction and Isolation of Polyphenolics. Current Protocols in Food Analytical Chemistry. I:I1:I1.2. doi: 10.1002/0471142913.fai0102s06.

Mancinelli AL (1990) Interaction between Light Quality and Light Quantity in the Photoregulation of Anthocyanin Production. Plant Physiology 92: 1191-1195. doi: http://dx.doi. org/10.1104/pp.92.4.1191.

Manivannan P, Jaleel CA, Sankar B, Kishorekumar A, Somasundaram R, Lakshmanan GMA, Panneerselvam R (2007) Growth, biochemical modifications and proline metabolism in Helianthus annuиs L. as induced by drought stress. Colloids and Surfaces B: Biointerface 59: 141-149. doi:10.1016/j.colsurfb.2007.05.002.

Manna C, D'Angelo S, Migliardi V, Loffredi E, Mazzoni O, Morrica P, Galletti P, Zappia V (2002) Protective effect of the Phenolic fraction from virgin olive oils against oxidative stress in Human Cells. Journal of Agricultural Food Chemistry 50:6521-6526. DOI: 10.1021/jf020565+.

McDermitt DK, Norman JM, Davis JT, Ball TM, Arkebauer TJ., Welles JM, Roerner SR (1989) $\mathrm{CO}_{2}$ response curves can be measured with a field-portable closed-loop photosynthesis system. Annales des Sciences Forestières 46: 416-420.

McKay DL, Chen CY, Saltzman E, Blumberg JB (2009) Hibiscus sabdariffa L. tea (tisane) lowers blood pressure in prehypertesive and mildly hypertensive adults. The Journal of Nutrition 140: 298-303. doi: 10.3945/jn.109.115097.
Miyashita K, Tanakamaru S, Maitani T, Kimura K (2005) Recovery responses of photosynthesis, transpiration, and stomatal conductance in kidney bean following drought stress. Environmental and Experimental Biology 53: 205-214. doi:10.1016/j.envexpbot.2004.03.015.

Morton J (1987) Roselle. In: Morton JF (Eds.) Fruits of warm climates. Creative Resource Systems, Inc. Box 890, Winterville, N.C. 28590, Pp. 281-286. Available on http://www.hort.purdue.edu/newcrop/morton/roselle.html.

Nacif de Abreu I, Mazzafera P (2005) Effect of water and temperature stress on the content of active constituents of Hypericum brasiliense Choisy. Plant Physiology and Biochemistry 43: 241-248. doi:10.1016/j.plaphy.2005.01.020.

Ogbonnaya CI, Nwalozie MC, Roy-Macauley H, Annerose DJM (1998) Growth and water relations of Kenaf (Hibiscus cannabinus L.) under water deficit on sandy soil. Industrial Crops and Products 8:65-76. doi:10.1016/S09266690(97)10011-5.

Olaleye MT (2007) Cytotoxicity and antibacterial activity of methanolic extract of Hibiscus sabdariffa. Journal of Medicinal Plants Research 1: 009-013.

Parida AK, Dagaonkar VS, Phalak MS, Umalkar GV, Aurangabadkar LP (2007) Alterations in photosynthetic pigments, protein and osmotic components in cotton genotypes subjected to short-term drought stress followed by recovery. Plant Biotechnology Reports 1:37-48. doi: 10.1007/s11816006-0004-1.

Pieters AJ, El Souki S (2005) Effects of drought during grain filling on PS II activity in rice. Journal of Plant Physiology 162: 903-911. doi:10.1016/j.jplph.2004.11.001.

Ponder DM, Al-Hamdani SH (2011) Selected physiological responses of Kudzu to different levels of induced water stress. Journal of the Alabama Academy of Science 82: 44-53.

Praxedes SC, DaMatta FM, Loureiro ME, Ferrao MAG, Cordeiro AT (2006) Effects of long-term soil drought on photosynthesis and carbohydrate metabolism in mature robusta coffee (Coffea canephora Pierre var. kouillou) leaves. Environmental Experimental Botony 56: 263-273. doi:10.1016/j.envexpbot.2005.02.008.

Saibo NJM, Lourenco T, Oliveira MM (2009) Transcription factors and regulation of photosynthetic and related metabolism under environmental stresses. Annals of Botany 103: 609-623. doi: 10.1093/aob/mcn227.

Sanchez-Rodriguez E, Rubio-Welhelmi MM, Cervilla LM, Blasco B, Rios JJ, Rasles MA, Romero L, Ruiz JM (2010) Genotypic differences in some physiological parameters symptomatic for oxidative stress under moderate drought in tomato plants. Plant Science, 178: 30-40. 
Schuppler U, He PH, John PC, Munns R (1998) Effect of water stress on cell division and cell-division-cycle 2-like cellcycle kinase activity in wheat leaves. Plant Physiology 117: 667-678. doi: http://dx.doi.org/10.1104/pp.117.2.667.

Smirnoff N (1993) The role of active oxygen in the response of plants to water deficit and desiccation. New Phytologist 125:27-58. doi: 10.1111/j.1469-8137.1993.tb03863.x.

Smith JHC, French CS (1963) The major and accessory pigments in photosynthesis. Annual Review of Plant Physiology 14: 181-224. doi: 10.1146/annurev.pp.14.060163.001145.

Subramanian VB, Maheswari M (1990) Stomatal conductance, photosynthesis and transpiration in green gram during, and after relief of, water stress. Indian Journal of Experimental Biology 28: 542-544.

Terzi R, Kadioglu R (2006) Drought stress tolerance and the anti-oxidant enzymes system in Ctenanthe setosa. Acta biologica cracovensia series botanica 48: 89-96.

Tripathy BC, Oelmuller R (2012) Reactive oxygen species generation and signaling in plants. Plant Signaling Behavior 7: 1621-1633. doi: 10.4161/psb.22455.

Visioli F, Bellomo G, Galli C (1998) Free-radical-scavenging properties of olive oil polyphenols. Biochemical Biophysical
Research Communication 247:60-64. doi:10.1006/bbrc.1998.8735.

Vu JCV, Gesch RW, Allen LH, Boote KJ, Bowes G (1999) $\mathrm{CO}_{2}$ enrichment delays a rapid, drought-induced decrease in Rubisco small subunit transcript abundance. Journal of Plant Physiology 155: 139-142. doi:10.1016/S0176-1617(99)801564.

Westgate ME, Boyer J (1985) Osmotic adjustment and the inhibition of leaf, root, stem, and silk growth at low water potentials in maize. Planta 164:540-549. doi: 10.1007/BF00395973.

Widodo W, Vu JCV, Boote KJ, Baker JT, Allen LH Jr. (2003) Elevated growth $\mathrm{CO}_{2}$ delays drought stress and accelerates recovery of rice leaf photosynthesis. Environmental Experimental Biology 49: 259-272. doi:10.1016/S00988472(02)00091-6.

Xu Z, Zhou G, Shimizu H (2010) Plant responses to drought and rewatering. Plant Signaling Behavior 5: 649-654. doi: 10.4161/psb.5.6.11398.

Yin MC, Chao CY (2008) Anti-Campylobacter, anti-aerobic, and anti-oxidative effects of roselle calyx extract and protocatechuic acid in ground beef. International Journal of $\begin{array}{llll}\text { Food } & \text { Microbiology } & \text { 127: } & \end{array}$ doi:10.1016/j.ijfoodmicro.2008.06.002. 